\title{
Performance and Quality of Chiltepín (Capsicum annum L.) Produced Under Open Air Conditions in Xicotepec of Juarez, Puebla
}

\section{Calidad pre y postcosecha de Chiltepín (Capsicum annum L.) Producido Bajo Condiciones de Cielo Abierto en Xicotepec de Juárez, Puebla}

GALLARDO-SANDOVAL, Araceli*†, MORALES- GUZMÁN, Víctor, MORALES-CALVA, Esteban and RIOS-TORRES, Ana María

Universidad Tecnológica de Xicotepec de Juárez, Puebla, Programa Educativo de Ingeniería en Procesos Alimentarios.

ID $1^{\text {st }}$ Author: Araceli, Gallardo-Sandoval / CVU CONACYT ID: 320066

ID $1^{\text {st }}$ Coauthor: Víctor, Morales- Guzmán / ORC ID: 0000-0003-3098-2124, Researcher ID Thomson: S-7585-2018, CVU CONACYT ID: 320063

ID $2^{\text {nd }}$ Coauthor: Esteban, Morales-Calva

ID $3^{\text {rd }}$ Coauthor: Ana María, Rios-Torres

DOI: $10.35429 / E J R C .2019 .9 .5 .24 .28$

Received July 27, 2019; Accepted December 20, 2019

\begin{abstract}
The Capsicum plant develops naturally and comprises the majority of domesticated chile in Mexico. The fruit presents gastronomic, cosmetic and pharmaceutical uses. The economic and commercial value of the Piquín pepper is due to the nutritional contribution and content of carotenoids, vitamin $\mathrm{C}$ and tocopherols. The study was conducted at the Technological University of Xicotepec de Juárez, Puebla, Mexico. Pests and / or diseases in culture were identified using 50 random plants, Capsaicin content (HPLC), fresh weight (AOAC), and color (Hunter $\mathrm{Lab}{ }^{\circledR}$ ) in fruit. The pests and diseases found were: spider (Tetranichus urticae), white mosquito (Trialeurodes vaporariorum), chicharita (Empoasca spp), aphid (Bactericera cockerelli Sulc.), Cricket (Acheta assimilis) and blight (Xanthomonas campestris) with incidence rate of: $4 \%, 6 \%, 4 \%, 4 \%, 58 \%$ and $6 \%$, respectively. The fresh weight of the fruit was $0.13 \mathrm{~g}$, the values for color L: 14.42; a: 12.37 b: 6.47 indicate opacity, tending to dark red, stem growth was 4 to $18 \mathrm{~cm}$, capsaicin content of $168 \mu \mathrm{g} / \mathrm{mL}$. Piquín pepper has a high content of carotenes related to chronic degenerative diseases, oxidative stress, cancer, etc. The plant during its low incidence of diseases that do not affect the development of the fruit.
\end{abstract}

Capsicum, Capsaicin, Pests, Diseases

\begin{abstract}
Resumen
La planta del género Capsicum se desarrolla de manera natural y comprende la mayoría de los chiles domesticados en México. El fruto presenta usos gastronómico, cosmético y farmacéutico. El valor económico y comercial del chile piquín se debe al aporte nutrimental y contenido de carotenoides, vitamina $\mathrm{C}$ y tocoferoles. El estudio se realizó en la Universidad Tecnológica de Xicotepec de Juárez, Puebla, México. Se identificaron plagas y/o enfermedades en cultivo usando 50 plantas al azar, contenido de Capsaicina (HPLC), peso fresco (AOAC), y color (Hunter Lab®) en fruto. Las plagas y enfermedades encontradas fueron: araña (Tetranichus urticae), mosquita blanca (Trialeurodes vaporariorum), chicharita (Empoasca spp), pulgón (Bactericera cockerelli Sulc.), grillo (Acheta assimilis) y tizón (Xanthomonas campestris) con porcentaje de incidencia de: $4 \%, 6 \%, 4 \%, 4 \%, 58 \%$ y $6 \%$, respectivamente. El peso fresco del fruto fue $0.13 \mathrm{~g}$, los valores para color L: 14.42; a: 12.37 y b:6.47 indican opacidad, tendiente al rojo oscuro,el crecimiento de tallo fue de 4 a $18 \mathrm{~cm}$, el contenido de capsaicina de $168 \mu \mathrm{g} / \mathrm{mL}$. El chile piquín tiene alto contenido de carotenos relacionados con enfermedades crónico degenerativas, estrés oxidativo, cáncer, etc. La planta durante su presenta baja incidencia de enfermedades que no afectan en el desarrollo del fruto.
\end{abstract}

Capsicum, Capsaicina, Plagas, Enfermedades

Citation: GALLARDO-SANDOVAL, Araceli, MORALES- GUZMÁN, Víctor, MORALES-CALVA, Esteban \& RIOSTORRES, Ana María. Performance and Quality of Chiltepín (Capsicum annum L.) Produced Under Open Air Conditions in Xicotepec of Juarez, Puebla. ECORFAN Journal-Republic of Cameroon. 2019, 5-9: 24-28

\footnotetext{
* Correspondence to Author (email: araceli.gallardo@utxicotepec.edu.mx)

$\dagger$ Researcher contributing first Author.
} 


\section{Introduction}

Since years ago, Mexico has been listed as a highly consumer country in spicy products, such as chili (Capsicum), a crop that is widely distributed from the north of the country to South America, from which various species are derived, depending on the region and the type of vegetation, one of them is the Chiltepin (Capsicum annum L.); fruit considered as a significant element for cultures in the preparation of traditional dishes and medicine (Coronado et. al., 2013; Bañuelos et.al, 2008; Medina et al., 2010).

In Mexico, the cultivation of chili continues to be an agricultural practice based on customs and traditions. In the region of the Sierra Norte of the State of Puebla, chiltepin is produced wildly and sometimes in orchards in combination with coffee plants, where it has low yield and variability in fruit quality (Morales et al. 2018).

The objective of this work was to identify the main pests and diseases in Chiltepin culture and determine the quality of the fruit under open field conditions in Xicotepec de Juárez, Puebla, Mexico.

\section{Theoretical framework}

Chiltepin or chile piquín (Capsicum annum L.) is one of the more than 20 varieties in Mexico, with physiological differences in flower, plant, fruit and seed viability; considering wild varieties, improved, even genetically modified (Luna, 2012). The common name and how this species has been classified by different authors; The most common names are: chiltepin, chile de monte and chile piquín. The synonymous scientific names are: Capsicum aviculare L., C. frutescens L., C. baccatum L. and Capsicum annuum L (Martínez, 1979; Molina et al., 2009)

The chiltepin is characterized by being a perennial shrub 1.5 to $2 \mathrm{~m}$ tall, has a dense crown, thin and flexible branches. The leaves are flat, simple and oviodes-lanceolate 2 to $6 \mathrm{~cm}$ long and $1-3 \mathrm{~cm}$ wide. Stem 20 to $50 \mathrm{~cm}$ long and has a fibrous root. The flowers are white and perfect, forming in the armpits of the branches. The petals and sepals formed by 5 pieces, the peduncle is straight and thin 1.5 to $3 \mathrm{~cm}$ long.
The reproductive maturity of the plant is between 6 and 10 months (Cortés and Valdez, 2001; Molina et al., 2009). The fruit is oval and slightly conical, green when immature, red when ripe and almost always sepia red when dried, 1 to $2 \mathrm{~cm}$ long and half a centimeter or less wide.

The production of dried chili worldwide has increased due to the uses of the fruit, such that FAO reports that by 2013 world production was 3.4 million tons, with India being the main producer with 1.4 million tons; Mexico participating with almost 60 thousand tons (FAO / STADISTICS, 2016).

In Mexico, there is a range of chili peppers grown under various management conditions, with habanero, serrano, poblano, tree, jalapeño and apple trees being the green species with the highest production and in the case of pasilla, guajillo and chiltepin dried chiles; Even the varieties are regionalized (Luna, 2012).

Chiltepin is a fruit that is highly appreciated and quoted for its flavor, spicyness and degree of pungency, reaching a cost in the direct consumer market of $\$ 500.00$ to $\$ 1000.00$ pesos per kilogram of dried fruit that comes mostly from wild plant collections (Parra et to ;; 2006)

Chiltepin is used for nutritional purposes as a spice because it contains vitamins such as $\mathrm{C}$, Riboflavin, Niacin, proteins, minerals, fiber and carotenes, but also contains the compound capsicin known for its antioxidant, expectorant and natural decongestant properties (Reboledo, 2004; Lambert and Sum, 2006)

\section{Materials and methods}

The variety of chiltepin used (Capsicum annum L.) was grown under open sky conditions, in the town of Xicotepec de Juárez, Puebla, Mexico that is 1050 meters above sea level, has a climate of (A) $\mathrm{Cb}(\mathrm{fm})(\mathrm{e}) \mathrm{gw}$ "semi-warm humid with rains throughout the year, the average temperature is $30^{\circ} \mathrm{C}$, Relative Humidity ranges between 50 and $70 \%$. The crop is in the experimentation garden of the AgroindustrialFood area of the Technological University of Xicotepec de Juárez, located at Av. Universidad Tecnológica No. 1000, Col. Tierra Negra. Samples to determine fruit quality were analyzed in the Chemistry and Food Analysis laboratories. 
50 random fresh fruits were collected and weighed on a portable digital scale $\left(\mathrm{OHAUS}{ }^{\circledR}\right.$ TA501, TravelerTM Series) to determine the weight in grams. Fruit color was determined using the HunterLab technique and previously dried fruits.

Samples of Piquín pepper (Capsicum annum L.) were obtained from the harvest in the UTXJ and from the market of the community of Xicotepec de Juárez. For the extraction, the pericarp and placenta of 50 nuts were obtained, subsequently mixed and pulverized. Of the powder obtained, $500 \mathrm{mg}$ was weighed on an electro analytical balance (Mettler Balance HR 160) and $5 \mathrm{~mL}$ of HPLC grade acetonitrile $(\mathrm{ACN})$ were added. Then he took a water bath at $60^{\circ} \mathrm{C}$ for 5 hours, stirring every 30 minutes. The supernatant was filtered $(2 \mathrm{~mL})$ by acrodisk (CHROMAFIL ${ }^{\circledR}$ Xtra PFPL-45/25 $0.45 \mu \mathrm{m}$ ) and deposited in an amber vial.

For the quantification of Capsaicin a column was used: Hypersil ODS, the measured wavelength was $202 \mathrm{~nm}$ and $246 \mathrm{~nm}$. The injection volume of $20 \mu \mathrm{L} .65 \% \mathrm{ACN}$ and $35 \%$ monobasic potassium phosphate solutions were used. The temperature was $28^{\circ} \mathrm{C}$, the flow of $1.7 \mathrm{~mL}$. Stem growth was determined by germination in a tray to later transfer the seedling to the final soil. 100 plants were analyzed to determine the percentage of incidence of pests and diseases.

\section{Results and discussions}

The fruit quality parameters determined in the study (Table 1) show that the fresh weight is 0.13 $\mathrm{g}$, being one of the smallest peppers in Mexico. It is a fruit of dry consumption, the concentration of the red-orange colors are presented with greater intensity due to the carotenes that provide these colors, in addition to being highly demanded for the health benefit (Rodríguez et al .; 2015; Montoya 2009).

\begin{tabular}{|l|c|c|c|c|c|}
\hline Muestra & \multicolumn{3}{c}{ Color } & \multicolumn{2}{c|}{$\begin{array}{c}\text { Capsaicina } \\
(\boldsymbol{\mu g} / \mathbf{1 0 0 m L})\end{array}$} \\
& Leso fresco (g) \\
\hline & L & a & b & & \\
\hline M1 & $14,5 \pm 0,4$ & $14,5 \pm 0,4$ & $6,478 \pm 0,3$ & $168 \pm 4$ & $0,13 \pm 0,01$ \\
\hline M2 & $14,8 \pm 0,2$ & $12,4 \pm 1$ & $5,8 \pm 0,8$ & $178 \pm 2$ & -- \\
\hline
\end{tabular}

Table 1 Physicochemical and nutritional properties of Chiltepin: color (HunterLab scale), fresh weight (g) and Capsaicin content $(\mu \mathrm{g} / 100 \mathrm{~mL})$
Stem growth (Figure 1) showed significant variability with an average of 8.95 $\mathrm{cm}$, a factor that derives from moisture, amount of water in soil, temperature and soil nutrients. The crop presented suitable growth characteristics without showing alteration in the plant, behavior that can be used to establish the crop under open sky and / agroforestry condition (Molina et al., 2009), presenting market opportunities and fruit transformation (Montoya, 2009 ).

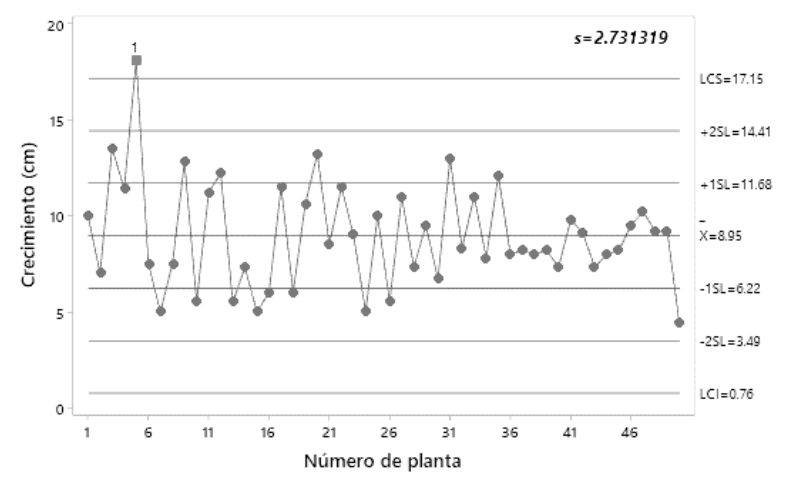

Figure 1 Stem growth $(\mathrm{cm})$ in chiltepin plant for 15 days (measurements every 8 days)

The main identified pests were spider (Tetranichus urticae), white mosquito (Trialeurodes vaporariorum), chicharita (Empoasca spp), jumping aphid (Bactericera cockerelli Sulc.) And cricket (Acheta assimilis), the incidence rate was $4 \%, 6 \%, 4 \%, 4 \%$ and $58 \%$, respectively (Figure 3 ).

The diseases that appeared were blight (Xanthomonas campestris) and Alternaria (Alternaria solani), the incidence rate was 6 and $1 \%$, respectively (Figure 3 ), however the genus Capsicum in intensive open-field systems has presented Phytophthora capsici , Fusarium spp and Rhizoctonia solani, showing symptoms such as wilting in plant and fruit, yellowing and rot (Chew et al. 2008; González et al., 2002)

In general, the Piquín pepper has a low incidence in pests and diseases as long as they are preventive methods in their cultivation and sporadically they present insects that damage the foliage, observing that it increases its incidence in intensive crops (Mena, 2004; Rodríguez et al, 2003). 

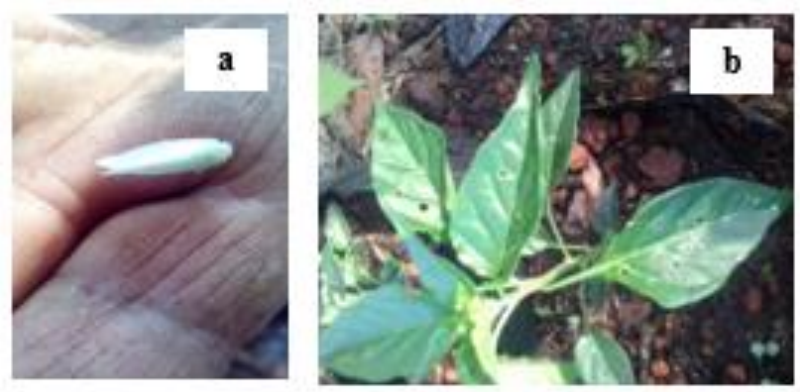

Figure 2 Plague: a) white mosquito (Trialeurodes vaporariorum); b) cricket damage (Acheta assimilis)

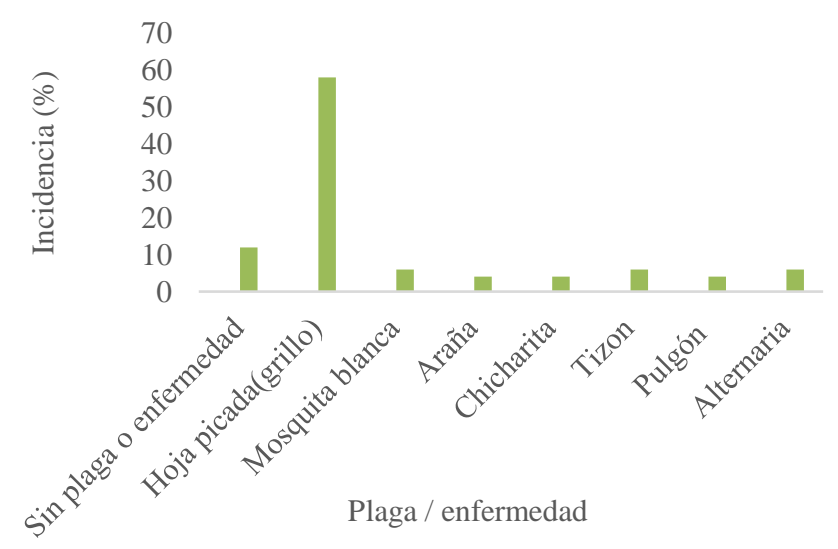

Figure 3 Incidence (\%) of pests and diseases in Chiltepin culture

Capsaicinoids (Table 1), in addition to participating in the itching of the fruit, are compounds that present different biological activities with beneficial effects for human health, among which the stimulation of the cardiovascular system (Govindarajan and Sathyanarayana, 1991), the capacity antiinflammatory (Anogianaki et al., 2006), and anticancer effect (Choi et al., 2006). In addition, it is the active ingredient for safety weapons such as tear gas (Busker and van Helden, 1998). Also, carotenoids have antimicrobial activity, Massod et al (1994) established that the antifungal activity shown by Capsicum anuum was due to capsantin and capsaicin.

\section{Conclusions}

Chiltepin is a wild crop in the Sierra Norte of the State of Puebla, has adequate average growth characteristics of $8.8 \mathrm{~cm}$ per week, monitoring the cultivation with foliar fertilization $(\mathrm{N})$, irrigation, $\mathrm{pH}$ and organic matter content in soil.
The pests that appeared in chiltepin were spider (Tetranichus urticae), white mosquito (Trialeurodes vaporariorum), chicharita (Empoasca spp), aphid (Bactericera cockerelli Sulc.) And cricket (Acheta assimilis), although with low incidence $<7 \%$, a Except for the cricket (Acheta assimilis) that occurred in more than $50 \%$ of the cultivated plants, however the fruit production was not affected.

The content of Capsaicinoids in fruits such as chiltepin, are highly referred to health, since they are related to uses in gastrointestinal diseases, cancer and antioxidant effect.

\section{Acknowledgments}

The Technological University of Xicotepec de Juárez Puebla for supporting this research.

\section{References}

Anogianaki , A., Negrev, N.N., Shaik, Y.B., Castellani, M.L., Frydas, S., Vecchiet, J., Tete, S., Salini, V., De Amicis, D., De Luttis, M.A. , Conti, F., Caraffa, A., Cerrulli, G. ( 2006 ). Capsaicin an irritant anti-inflammatory compound. Journal of Biological Regulators and Homeostatic Agents 2(6), 1-4.

Busker R.W. y Van Helden, H.P. 1998. Evaluación toxicológica del spray de pimienta como posible arma para la fuerza policial holandesa: evaluación de riesgos y eficacia. Soy J Forensic Med Pathology 19 (4): 309-16.

Bañuelos, N., Salido, P. L. y Gardea, A. 2008. Etnobotánica del chiltepín. Pequeño gran señor de la cultura de los Sonorenses. Centro de Investigación y Desarrollo A.C. 16 (32), pp. 730.

Chew, M. Y. 1., Piña, A. V., Rodríguez, M. P., \& Díaz, f. J. (2008). Principales Enfermedades Del Chile (Capsicum accuun). Coahuila Mexico: SAGARPA.

Choi Suk-Hyun, L., Bong-Soon, S., Kozukue, E., Kozukue, N., Levin, C., Friedman, M. (2006). Analysis of the contents of pungent compounds in fresh korean red peppers and in pepper-containing foods. Journal of Agricultural and Food Chemistry 54, 9024- 9031 
Coronado G., M. A., Córdova Y., A., García P., M., Santiago H., V.G. y Vásquez Navarro, R.A. 2013. Estrategias de mercado para productos elaborados a base de chiltepín en la sierra de Sonora. Revista Mexicana de Agronegocios. 17(32), pp. 359-370

Cortés Melgar, N. y Valdés Aguayo, H. 2001. El chiltepín una alternativa de ingresos. Revista técnico informativa de patrocipes: Rancho. 4 (1); pp. 3-6

González, Ch. M.M., Torres P. I. y Guzmán, M.H. 2002. Patógenos involucrados en la marchitez de chile. In: Proceedings of the 16th International Pepper Conference. Tampico, Tamaulipas, México. Noviembre 10-12.

Luna R., José de J. 2012. Aplicaciones de los SIG para el análisis de flujo genético potencial entre chiles silvestres y cultivados en la República Mexicana. Centro de Ciencias Agropecuarias de la Universidad Autónoma de Aguascalientes, México.

Lambert, J. W. y Sum, A. K. (2006). Molecular dynamics study of the properties of capsaicin in an 1-Octanol/Water System. The Journal of Physical Chemistry 110, 2351-2357

Masood, A., Dogra, J.V.V., Jha, A.K. (1994). "The infl uence of colouring and pungent anents of red chilli (Capsicum annuum) on growth and aflatoxin production by Aspergillus flavus". Letters in applied microbiology, 18: 184-186.

Medina- Martínez, T., Villalón- Mendoza, H., Pérez Hernández, J., Sánchez Ramos, G., \& Salinas Hernández, S. (2010). Avances y perspectivas de investigación del chile piquín. Redalcic.org, 16-21.

Mena García, L. (2004). El cultivo de Chile Piquín (Capsicum annum, var aviculare Dierb) (Licenciatura). Universidad Autónoma Agraria "Antonio Narro."

Morales, G.V., Morales, C.E., Gallardo, S.A. y Ortega, R.L. (2018). Evaluación de Chiltepín (Capsicum annum L.) Producido bajo condiciones de invernadero en Xicotepec de Juárez, Puebla. Revista de Ciencias Ambientales y Recursos Naturales. México. 14 (4) pp: 37-40
Molina, M.C; Morales, C.A. y Márquez, C.A. (2009). Técnicas para el establecimiento y producción de chiltepín silvestre, bajo un sistema agroforestal en Sonora, México. Comisión Nacional Forestal, SEMARNAT. Manual Técnico. Sonora, México.

Montoya, B. L. C. (2009). Calidad y valor agregado en chiltepín. Memoria. Foro Comunitario de chiltepín Región Río Sonora "El picante Sonorense". Organizado por CONAFOR, SEMARNAT, México. 22 de abril de 2009

Organización de las Naciones Unidas para la Alimentación y la Agricultura, Dirección de estadística (FAOSTAT). Mayo 2016

Consultar:

http://faostat3.fao.org/browse/Q/QC/S

Parra, G.C.G., Sánchez, M.D.I., López, J., Ulloa, R.G.A. Norma (2006). Efecto del ácido giberélico sobre la capacidad de germinación de semillas de chiltepín (Capsicum frutescens). Instituto Tecnológico de Sonora, Departamento de Biotecnología y Ciencias Alimentarias. Tesis de titulación. Instituto tecnológico de Sonora, Departamento de Biotecnología y Ciencias Alimentarias, Sonora, México.

Rodríguez, B.L., Ramírez, M.M. y Pozo, C.O. 2003. Tecnología de Chile piquín en el Noreste de México. INIFAP-CIRNE. Campo experimental Río Bravo. Folleto Técnico No. 5, Tamaulipas, México. pp. 1-13.

Rodriguez, M. A., Troncoso, R. R., Sánchez, E.A., González, M. D., Ruiz, S. E., Zamora, B. R., Ceceña, D. C., Grimaldo, J. O. y Aviles, M. M. (2015). Efecto antifúngico de extractos fenólicos y de carotenoides de chiltepín (Capsicum annum var. glabriusculum) en Alternaria alternata y Fusarium oxysporum. Revista Argentina de Microbiología. 47(1): pp. 72-77 